\title{
Integrated Water Resources Management
}

\author{
Per Stålnacke • Geoffrey D. Gooch
}

Published online: 18 December 2010

(C) Springer Science+Business Media B.V. 2010

\section{Introduction}

Despite increases in awareness of integrated water resources management (IWRM) and a number of studies that focus on the concept there still exist few in-depth scientific studies on the rationale behind the principles and concepts. Moreover, as Gooch and Stålnacke (2006) have pointed out, IWRM definitions and concepts, which focus on and influence thinking about sustainability, do not provide us with much indication of how this proposed co-ordination, balancing and integration is to be achieved in practice.

This special issue of Irrigation and Drainage Systems is dedicated to the topic of IWRM. The nine papers included here provide overviews of the subject, address key sets of selected key challenges in IWRM, provide new data, and, most importantly, give food for thought around IWRM as a contemporary issue. In the following sections of this introduction, the nine articles in this special issue are summarized and placed into an overall context. Each of the articles contributes to a greater understanding of IWRM in different ways. Finally, some overall conclusions in the form of concluding remarks are provided. Hopefully this special issue will help to 'open up' the 'IWRM-box'. We also hope that the articles will inspire further interest and research into the topic that will then provide further support in the local, regional, national, transnational and global management arenas and in academic institutes.

In addition, this special issue complements two closely related new textbooks on water resources management (Gooch and Stålnacke 2010; Gooch et al. 2010).

P. Stålnacke $(\square)$

Bioforsk-Norwegian Institute of Agricultural and Environmental Research, FA Dahls vei 20, 1432 Ås, Norway

e-mail: per.staalnacke@bioforsk.no

G. D. Gooch

Department of Management and Engineering, Linköping University, 58183 Linköping, Sweden e-mail: geoffrey.gooch@liu.se

G. D. Gooch

University of Dundee, Centre for Water Law, Policy and Science, Nethergate, Dundee DD1 4HN

Scotland, UK

e-mail: g.d.gooch@dundee.ac.uk 


\section{Developments in IWRM and its principles}

The roots of Integrated Water Resources Management (IWRM) can be traced back to the establishment of the Tennessee Valley Authority (TVA) in 1933 (Adams 2001). The next major milestone in the development of the concept was in 1977 at the International Water Conference in Mar del Plata. The emphasis of this conference was on coordination between different water sectors, primarily at the national authority level (Snellen and Schrevel 2004). These issues were given further attention at the 1992 Dublin conference, preparing for the Earth Summit in Rio de Janeiro. The Dublin statement included the following four principles:

(1) Fresh water is a finite and vulnerable resource, essential to sustain life, development and the environment.

(2) Water development and management should be based on a participatory approach, involving users, planners and policy-makers at all levels.

(3) Women play a central part in the provision, management and safeguarding of water.

(4) Water has an economic value in all its competing uses and should be recognized as an economic good.

In this issue, Nesheim et al analyse IWRM status in four river basins in different parts of the globe based on a selection of four of these principles (see Nesheim et al). The four principles relate to different aspects of sustainable development-environmental, social, economic and institutional-as well as a factor that is especially important in many countries of the South, the capacity to implement IWRM. The paper points out that laws and policies must be implemented to be effective.

In 1998, the European Commission (EC) published a series of Guidelines for Water Resource Development Cooperation entitled "Towards Sustainable Water Resources Management: A Strategic Approach" (EC 1998). The Strategic Approach provided a major contribution to the translation of the international consensus on integrated water resources management (IWRM) into development cooperation activities. In this special issue, Walmsley and Pearce analyse this guideline document and claim that the core structure and philosophy behind the Strategic Approach remains valid. However, they also propose that there is a need for a number of enhancements which are identified in the paper, in order to ensure that it remains up-to date and responds to current thinking and practice.

Later important milestones were the Millennium Development Goals adopted in 2000, and the Johannesburg Summit on Sustainable Development in 2002 (http://www.un.org/ jsummit/html/basic_info/basicinfo.html). Both conferences advocated that there is a need to go further than to just include the co-ordination of sectors and agencies. Muller (in this special issue), conducted a comparative analysis of sovereign (i.e., Mexico, Chile, China, South Africa, Tunisia and Denmark) and donor-dependent countries (i.e., Sri Lanka, Uganda, Mozambique, Kenya, and Sudan) seen in the light of the Dublin and Rio principles. Muller argues that countries that have followed the Rio-principles have been more successful than those following the Dublin-principles.

In Europe, the Water Framework Directive (EC 2000) together with the recent Marine Strategy Directive (EC 2008) provided the legislative and policy structure for operational integrated water resources management. These directives and their influence on the IWRM discourse are not covered in this special issue, except some aspects of public and stakeholder participation (see the section on 'The science-policy-stakeholder interface' below).

In the 2000s many scientific publications and grey-literature reports on IWRM started to appear. A summary of these can be found in Gooch and Stålnacke (2010) and 
Gooch et al. (2010). A summary of the critiques of IWRM can also be found in the paper by Muller. The point we would like to stress here is that overall conceptual IWRM 'thinking', entry-points into the approach and the approach itself can differ substantially (Gooch et al. 2010).

Thus there are can be significantly different interpretations and mind-frames around IWRM and this should be kept in mind when reading the individual papers in this special issue.

\section{IWRM assessment and methodologies}

Both the scientific and the management community agree that the framework and concept of integrated water resources management-IWRM-lacks clear methodologies. In the article in this special issue by Nesheim et al., the focus was to provide a detailed assessment of the current status of IWRM within four case study basins, and also to identify knowledge gaps where more information needs to be collected. The assessment was aimed not only at assessing to which degree IWRM components could be found in the basins, but also at evaluating the processes towards implementing IWRM in the different basins. This was performed by analyzing planning documents in each basin. The authors show that the implementation of IWRM is still at a fairly early stage in all the four basins; and that successful implementation of water resources is dependent not only on the existence of relevant policies, but also the degree to which laws and policies are in fact implemented.

The paper by Allan and Rieu-Clarke in this issue also deals with IWRM assessment methodologies; their point of entry focuses however on how to measure good governance in an IWRM context. They stress the crucial role of law and legal arenas and more specifically they claim that accountability, participation and transparency are crucial for good governance and that there is a need to find the connectivity points between these governance factors and the IWRM process.

\section{The science-policy-stakeholder interface}

The science-policy interface is also covered in the paper by Quevauviller (this issue). He states in his conclusion that IWRM will be achievable in practice if operational links are ensured between knowledge providers and practioners. In the paper, various mechanism and initiatives at the EC-level are discussed. At the same time, Quevauviller argues that the framework that links water policies to the R\&D life cycle is presently lacking.

Besides the challenges of a pure science-policy interface, there is also a need to involve stakeholders in the IWRM process. Vinke-de Kruijf et al. (this issue) show, through a discussion of two case studies in the delta region in the Netherlands, the crucial role of an open problem formulation phase in IWRM. This is necessary for the successful structuring of a problem and stresses the need for a fully transparent knowledge base (expert-based or derived by the stakeholder themselves). The authors discuss the process needed to arrive at "negotiated knowledge", i.e. a knowledge base on which stakeholders agree concerning issues such as validity, significance and meaning. The importance of involving stakeholders is also presented in the papers by Nesheim et al, Skarbøvik et al and Allan and Rieu-Clarke. 


\section{The importance of scientific facts and figures}

The important role of reliable data such as water quality measurement is indisputable. This is not only a natural scientific dogma but also largely recognized by various international water management bodies. For example, the theme of the World Water Day in 2010 was in fact 'water quality'. On this day the International Water Association stressed "the urgent need to step up research, monitoring and assessment of water quality at global, regional, and local levels". The role of research results as inputs to sound policy formation and implementation was also high-lighted as another core message. Scientific studies have also shown that reliable data that all parties can trust are crucial for the knowledge-based management of water resources (e.g. Timmerman and Langaas 2004, 2005, Stokke 2006)

In this special issue, Skarbøvik et al. stress the need for reliable data and information as an important basis for integrated water resources management (IWRM). Such data are especially important in transboundary water bodies, as they can represent a common and transparent knowledge-base that all concerned parties can trust and utilise in the management process. Their case study area was the transboundary Lake Macro Prespa (West Balkan). Important results from these authors include that water quality monitoring can give inadequate or even erroneous information if all steps of the data aquisition are not thoroughly understood and quality assured, and that the lack of accreditation and inter-comparisons between laboratories was the main challenge for obtaining reliable water quality data in this case study.

Another paper in this issue discusses the problem around various survey-based methods of economic valuation of water (Barton and Taron). The authors show that the significant variation in implicit willingness to pay for irrigation water also indicates that uniform pricing schemes will create resistance within a single command area, as well as across command areas in a river basin, because of the large differences in access to water.

\section{Global change and land-water interactions}

The comprehensive paper in this special issue by Bonell discusses the uncertainties around land-cover and land-use changes on climate-water relations, climate variability and predicted climate change scenarios. Bonell argues with several cases from tropical regions that these couplings still remain a major challenge to quantify. Moreover, he calls for more concentrated research efforts within the outer margins of the 'maritime continent' (whose axis is centered on the Indonesian Archipelago in the western Pacific) where tropical cyclone frequency is very high, e.g. The Philippines, northern Australia.

\section{Concluding remarks}

The nine papers in this special issue all contribute to our understanding of IWRM as a concept, and as a tool for the practical implementation of water management. We thank the contributors and hope that the knowledge provided in these papers will help water managers and academics alike to delve further into the concept of IWRM.

Acknowledgement We would like to thank the researchers who responded to this call and provided research results or reviews for this special issue.

Thanks also to the European Commission who provided the funding for the STRIVER project (Contract number: 037141) and the successful STRIVER conference (http://kvina.niva.no/striver/Meetings/STRIVER FinalConference/STRIVERFinalConferencedocuments/tabid/169/Default.aspx. 
Web-cast videos from some selected key presentations and panel discussion are available via the same web-page. Thanks also to the journal's Editor-in-Chief Prof Mark Svendsen for his interest in highlighting this important IWRM topic.

\section{References}

Adams WM (2001) Green development: environment and sustainability in the Third World, 2nd edn. Routledge, London

EC (1998) Towards sustainable water resources management: a strategic approach. European Commission Guidelines for Water Resources Development Co-operation. EC Publication

EC (2000) EU Water Framework Directive. (2000) Directive 2000/60/ EC of the European Parliament and the Council of 23 October 2000 establishing a framework for community action in the field of water policy. Official Journal of the European Communities (22.12.2000) L 327, 1)

EC (2008) Directive 2008/56/EC of the European Parliament and of the Council of 17 June 2008 establishing a framework for community action in the field of marine environmental policy (Marine Strategy Framework Directive). Official Journal of the European Union, 25.6.2008, L 164/19-164/40

Gooch GD, Stålnacke P (eds) (2006) Integrated transboundary water management in theory and practiceexperiences from the new EU Eastern Borders. IWA Publisher, London, pp 160

Gooch GD, Stålnacke P (eds) (2010) Science, policy and stakeholders in water management. Earthscan, London

Gooch GD, Rieu-Clarke A, Stålnacke P (eds) (2010) Integrating water resources management. IWA Publishing

Snellen WB, Schrevel A (2004) IWRM: for sustainable use of water-50 years of experience with the concept of integrated water management. Background document to FAO/Netherlands Conference on Water for Food and Ecosystems, http://www.fao.org/ag/wfe2005/docs/IWRM_Background.pdf

Stokke KB (2006) The Morsa River Basin, Norway: collective action for improving water quality. In: Rydin Y, Falleth EI (eds) Networks and institutions in natural resource management. Edward Elgar, Cheltenham, pp 123-138

Timmerman JG, Langaas S (2005) Water information: what is it good for? The use of information in transboundary water management. Reg Environ Change 5:177-187

Timmerman JG, Langaas S (eds) (2004) Environmental information in European transboundary water management. IWA Publishing, London, UK, pp 258 